\title{
'MAKING STRANGE': \\ DEFAMILIARISING PERSPECTIVES ON THE TROUBLES
}

\author{
STEPHANIE SCHWERTER
}

\section{Synopsis}

In Irish literature a substantial number of writers turn to different cultures and histories in order to contemplate on their own environment through the lens of otherness. In particular, poets from Northern Ireland draw upon contrasting literary traditions to articulate their personal experience of political violence through an international framework. In the poetry of Seamus Heaney, Tom Paulin and Medbh McGuckian a noticeably strong link between Northern Ireland and pre- and post-revolutionary Russia can be discerned. Through allusions to Russian literary figures, politicians and social conflicts, the three poets attempt to reconsider established power structures ingrained in Northern Irish society and challenge conventional interpretations of the Troubles. Employing Victor Shklovsky's technique of defamiliarisation, Heaney, Paulin and McGuckian take Russia as a point of comparison and contrast. In so doing, they attempt to generate a new vision of the Northern Irish situation and work against the traditionally one-sided discourse of the conflict. In the following article I analyse the different ways in which the three writers establish links to Russian literature, history and culture in order to give voice to their individual perceptions of contemporary Northern Ireland. In this context, I shall shed light on the reasons why they feel compelled to look outside their own culture in order to come to terms with the Northern Irish Troubles.

\section{Making strange}

Seamus Heaney, Tom Paulin and Medbh McGuckian are among the most influential Northern Irish poets, who turn to different literary traditions in order to explore contemporary Northern Ireland from a detached point of view. In their poetry, a strikingly strong link to pre- and post-revolutionary Russia can be discerned. According to Viktor Shklovsky's concept of 'ostraneniye', which literally translates as 'making strange' (cf. Shklovsky 1965: 3), they set out to reconsider the Northern Irish conflict through a defamiliarising framework. In a substantial number of their poems, the three writers establish parallels between Russia and Northern Ireland in terms of history, politics and culture, while at the same time creating correlations between themselves and various Russian authors. In this way, Heaney, Paulin and McGuckian generate an innovative outlook on 
the Troubles and encourage the reader to perceive the traditional discourse of the Northern Irish situation from an unconventional angle. By making the habitual appear to be out of the ordinary, they strive for clarity of vision and attempt to highlight the shortcomings of their own cultural environment. Heaney, in his poem 'Making Strange' (Heaney 1984: 32-33) suggests: “Go beyond what's reliable" and thus pleads for a widening of perspectives. Showing his home to a foreign person, the narrator of the poem begins to see his own country in a different light: "I found myself driving the stranger [...] reciting my pride in all that I knew, that began to make strange at the same recitation” (Heaney 1984: 3233). The alienating view in 'Making Strange' is created through the presence of a person from outside Ireland. In the poems explored in the article, this external perspective is generated through various references to Russia, which introduce an alternative vision. The three poems I have chosen for analysis offer representative examples of Heaney's, Paulin's and McGuckian's contrasting poetic approaches. In 'Chekhov on Sakhalin' by Heaney, 'The Other Voice' by Paulin and 'The Men with two Women' by McGuckian, the established links between Russia and Northern Ireland serve the three poets as a means to engage with the Northern Irish situation through the use of displacement.

\section{Seamus Heaney: 'Chekhov on Sakhalin'}

In 'Chekhov on Sakhalin' (Heaney 1984: 18), Heaney explores the intersections of politics and poetry, while establishing a parallel between the social inequality in Northern Ireland and the political oppression on the island of Sakhalin. In his poem, he evokes Anton Chekhov's journey to the prison island north of Japan, where the detainees of the Tsarist empire where held in appalling conditions, in many cases for unjustified reasons ( $c f$. Applebaum 2003: 15). Accused by various left-wing critics of being politically and socially uncommitted (cf. Ryfa 1999: 11), Chekhov decided to study the prisoners' living conditions in the penal colony. Throughout his stay on Sakhalin, he had to wrestle with his conscience, as he was torn between the feeling of having to take social action and his urge to engage with the prisoners' suffering imaginatively as a writer. Finally, he declared his expedition as 'his debt to medicine' (Chekhov 1977: xviii) and thus pointed out that only in his role as a medical doctor did he feel entitled to engage with the local situation.

In the first lines of 'Chekhov on Sakhalin', Heaney draws attention to the social engagement of the Russian writer:

So, he would pay his 'dept to medicine'.

But first he drank cognac by the ocean

With his back to all he travelled north to face.

(Heaney 1984: 18) 
In this stanza, Heaney evokes Chekhov's arrival on the island, when, shocked about the omnipresence of incarceration, the Russian writer emptied a bottle of cognac on his own. Looking at the ocean 'with his back to all he travelled north to face', Chekhov seems to have moved north in order to engage with the prisoners' situation. A glance at the map of Russia, however, reveals that the given directions are geographically incorrect, as Sakhalin is not situated north, but east of Moscow. Nevertheless, it is unlikely that the distortion of Russian geography is a mistake made by Heaney out of ignorance. The fact that the same geographic alteration is repeated in the first line of the third stanza, speaks for a conscious modification. The line 'That far north, Siberia was south' (Heaney 1984: 18) wrongly suggests Sakhalin's situation north of Siberia. It could be argued that Heaney intentionally employed directions interchangeably with the aim of giving them a symbolic meaning. In letting Chekhov travel 'north' instead of 'east', he establishes an implicit link between the Russian writer and himself. In this way, Heaney alludes to the fact that in his poetry, although geographically he moved south of the border, metaphysically his is still engaged with the Northern Irish conflict. Thus, he suggests that he is driven by the same social conscience as the Russian writer, following the urge to point out inequality and discrimination.

In 'Chekhov on Sakhalin', the 'north' turns into a symbol of isolation and seclusion. The line 'He felt the glass go cold in the midnight sun' again implies the geographical situation of Sakhalin in the very north. However, neither the North of Ireland, nor Sakhalin lies as far north as to get midnight sun in the summer. With his allusions to the far north, Heaney suggests that both islands distinguish themselves by geographical as well as spiritual remoteness. Whereas Ireland is situated on the western edge of Europe, Sakhalin lies east of continental Russia. In this way, he implies that the particular social structures of the two places have generated their own forms of society with a specific logic and functioning, often perceived as incomprehensible by people from outside. Apart from their geographical isolation, Heaney draws attention to the fact that both islands, which interestingly even share the same weather conditions, became the scenes of political injustice and oppression. He further implies that, being far from the 'centre', people living in troubled Northern Ireland were as much forgotten about as the prisoners on Sakhalin during the Tsarist era. Thus, Heaney points at the omnipresence of social injustice, existing regardless of time and space. He further implies that both the inhabitants of Northern Ireland and Sakhalin did not enjoy the deserved public attention.

Employing the tale of Chekhov's expedition to Sakhalin as a priyem ostraneniya, a 'device of making strange' (cf. Shklovsky 1965: 3-24), Heaney sets out to engage with his own concerns about the role of the poet in an environment marked by oppression and control. In the last two stanzas of his poem, he engages with Chekhov's search for artistic integrity and his quest for "inner freedom": 


\begin{abstract}
When he staggered up and smashed it on the stones It rang as clearly as the convicts' chains That haunted him. In the months to come It rang on like the burden of his freedom

To try for the right tone - not tract, not thesis -

And walk away from floggings. He who thought to squeeze

His slave's blood out and waken the free man

Shadowed a convict guide through Sakhalin.
\end{abstract}

(Heaney 1984: 18-19)

Through the term "slave's blood", Heaney alludes to the fact that Chekhov was the grandson of a serf. He presents the Russian writer's journey to Sakhalin as an act of liberation from his past, which enables him to become a "free man". In The Government of the Tongue, Heaney interprets Chekhov's expedition as a "halfconscious ritual of exorcism", allowing him to lay rest to his 'oppressed shadow self' (Heaney 1988: 18). With the description of Chekhov as being "haunted by the convicts' chains" and bearing his freedom as a burden, Heaney suggests that the Russian author has a guilty conscience. Thus, he draws attention to Chekhov's freedom to "walk away from the floggings" and to write about torture without being directly exposed to it. Through the illustration of Chekhov's moral torment, he addresses the question whether poetry may function as 'l'art pour l'art' or whether it should follow a politically motivated aim. Whereas Chekhov travels to the island to become spiritually independent through the liberation from his heritage, Heaney strives for artistic freedom desiring to break free from the ideological demands of his community. In The Redress of Poetry, he claims that Northern Irish poets were exposed to the pressure of society to adopt in their poetry a political position and to take the side of one of the antagonistic communities. Heaney himself, however, refuses to propagate a specific ideological point of view in his poems, as he considers poetry as a thought provoking "source of truth" (Heaney 1995: 93). Through the line "To try for the right tone - not tract not thesis”, Heaney evokes Chekhov's quest for a suitable form in which to present his findings on the prisoners' lives on Sakhalin. On a second narrative level, the line has to be interpreted as an allusion to Heaney's own search for an appropriate poetic voice to address the Troubles in Northern Ireland. Rejecting the text forms of "tract" and "thesis", he pronounces himself against a realistic approach in the representation of the conflict. Thus, he pleads for an imaginative engagement with the situation, which, "through the use of the right tone", does not escape reality. By means of the parallels created between Chekhov and himself, Heaney implies that both of them were tormented by the same moral and ethical questions. Consequently, he elevates his own considerations about the function of poetry to a universal problem, which is experienced by poets at different times of history in different political systems. 
The fact that 'Chekhov on Sakhalin' was written not long after the Hunger Strike of Republican prisoners in the Maze Prison in 1981 suggests that its content is most likely informed by the tense political situation in Northern Ireland. The captives on Russia's “Devil's Island” (Ryfa 1999: 9) echo the prisoners in the H-Blocks. Thus, Heaney establishes a link between the United Kingdom and the Russian Empire. Whereas the British establishment did not follow a reconcilary approach while dealing with the demands of Republican detainees, the Tsarist government refused to improve the captives' condition on the island (cf. Applebaum 2003: 15). Furthermore, Chekhov's ethical scruples about engaging with the local situation artistically mirror Heaney's hesitations about writing poems on the prisoners in the Maze Prison. Engaging with Chekhov's moral dilemma, Heaney emphasises the writer's duty to attract attention to the shortcomings in society without proclaiming a personal ideological standpoint. In this sense, it could be argued that Heaney follows Shklovsky's perception of art as a means to render things visible (cf. Shklovsky 1965: 12). Shklovsky suggests that the "technique of art is to make objects 'unfamiliar'” and "to make forms difficult" in order to capture the observer's attention (Shklovsky 1965: 12). Only if an object appears 'strange' will it be contemplated intensely. Once the perception of a certain object has become habitual, and thus 'automatic', it will not be noticed anymore. In relation to 'Chekhov on Sakhalin' this means that through the references to the Russian writer and his expedition to the island, Heaney attempts to shed an alienating light on the situation in Northern Ireland and sets out to give voice to his own ethical consideration about the purpose of poetry. In this sense, we could argue that Heaney tries to generate an external point of view, which, speaking in Shklovsky’s terms, has not been 'automatised' (cf. Shklovsky 1965: 11-12).

\section{Tom Paulin: 'The Other Voice'}

In 'The Other Voice', Paulin introduces a defamiliarizing perspective on Northern Ireland through the orchestration of contrasting voices. According to Bakhtin's concept of heteroglossia, the different voices in the poem are to be seen as world views or belief systems (Bakhtin 1981: 311), which become opposed to each other once they enter a dialogue. Thus, they generate a 'double voiced discourse' (Bakhtin 1981: 324) through which traditional perceptions become questioned and established ideological systems undermined. By means of various references to Russia, Paulin incorporates into his poem a multiplicity of perceptions and attitudes, shaped by a different culture and thus encourages new visions of the Northern Irish conflict. 'The Other Voice' was written in 1980, at a tense period of the Northern Irish conflict, which was leading up to the Hunger strikes in the Maze Prison. Considering the political situation, Paulin's quest for innovative ways, in which to address the local situation, seem to respond to a particular desire felt by the Northern Irish population. The poem moves between rural 
Ireland, Belfast, Moscow, St. Petersburg and Odessa, while numerous references are made to Russian politicians and writers such as Trotsky, Mandelstam and Dostoevsky. Starting off in the Northern Irish countryside, the setting begins to alternate between Belfast and Russia in the second stanza:

I lay claim to those marshes,

The Lagan, the shipyards,

The Ormeau Road in winter.

The black room off Donegall Pass,

Remember, where the cell met?

That cupboard of books, tracts, and poems?

(Paulin 1980: 42)

Mentioning the "shipyards" and the "Ormeau Road”, Paulin evokes Protestant Belfast $^{1}$ and implicitly hints at Unionism and the British presence in Northern Ireland. Through his allusion to "winter", he points at coldness, which could be interpreted as a reference to the chilliness of the political situation. The "back room off Donegall Pass", the meeting point of "the cell”, evokes subversion and political upheaval and stands in contrast to the aforementioned Protestant Belfast. The terms 'cell' and 'tracts' remind us of the Russian Revolution and thus of Marxist ideology. In the following stanza, Paulin moves to Russia, enforcing his references to Marxist thinking:

Plekhanov flares like a firework

Trotsky crosses Siberia

Turning the pages of Homer,

Raskolnikov wears a long coat

And the end justifies the means.

[...]

(Paulin 1980: 43)

With Plekhanov and Trotsky, Paulin introduces the voices of two historical thinkers, proclaiming a new social order. Gregory Valentinovich Plekhanov laid the basis for Russian Marxism and established the first Marxian revolutionary organisation in Russia in 1883, which was later joined by Vladimir Il'ytch Lenin. Describing Plekhanov as "flaring like a firework", Paulin alludes to the Russian politician's enthusiastic dissemination of revolutionary ideas. The image of a 'firework' stands in sharp contrast to the described 'winter' in Protestant Belfast. In this way, Paulin opposes the explosive power of new political ideas to the

\footnotetext{
${ }^{1}$ The Ormeau Road is situated in Protestant East Belfast and Belfast's shipyard has traditionally been the employer of members of the Protestant community.
} 
'frozen' state of British politics. Mentioning Trotsky, he introduces a further figure, embodying social change and political rebellion. Trotsky's "crossing of Siberia" alludes to his incarceration in Siberia, from which he managed to escape twice. The reference to Homer hints at Trotsky's 'odyssey' through Siberia, while returning to the capital. Whereas Plekhanov and Trotsky personify the struggle for a new form of society, Raskolnikov, the central character of Crime and Punishment, stands for unconventional philosophical thinking. In Dostoevsky's novel, Raskolnikov is a young impoverished intellectual, who decides to kill an old pawnbroker because her money could be used to help many others. With the line "the end justifies the means", Paulin does not only refer to Raskolnikov's utilitarian morality but also to the violent way, in which the ideas supported by Plekhanov and Trotsky were put into practice. Thus, Paulin throws up the question of the justifiability of violence on a general level, pointing subversively at Northern Ireland. He continues his poem with a move back to Belfast, a place which has been marked by political violence for a long time:

Soon the rosewood meubles

Will shake in the drawing-rooms

On the Malone Road

After the long marches

There will be shares for us all

In the means of production

Songs of a new society

Will grow like flowers

From the barrel of a gun.

$[\ldots]$

(Paulin 1980: 43)

Through his reference to the Malone Road, a mixed middle class area in South Belfast, Paulin evokes wealth and prosperity. In the context of 'The Other Voice', the allusion to the Malone Road reads as a subversive link to the Russian bourgeoisie, which the revolutionaries intended to dispossess and abolish. The "long marches" refer to the marching season, during which numerous marches are organised by the members of the loyalist Protestant community. Seen in a broader context, however, the 'marches' could be perceived as an allusion to the upheaval of the Northern Irish working class in general. In this way, the "rosewood meubles" and "drawing-rooms" on the Malone Road stand in sharp contrast to the marches of the working class. Referring to different social classes in Northern Ireland and establishing an implicit connection to the Russian bourgeoisie, Paulin presents the Northern Irish conflict as a class struggle and implies a parallel to the 
struggle of the Russian Proletariat. Thus, he creates a correlation between political upheaval in Northern Ireland and revolutionary Russia. With the line 'there will be shares for us all in the means of production', Paulin clearly adopts Marxist vocabulary, which he transposes to Northern Ireland. The sympathy he expresses in his poem with Marxist thinking can be explained by his own political background. Paulin was raised in Belfast's Protestant community and initially believed that social equality in Northern Ireland could be achieved if the region remained a part of the United Kingdom (cf. Paulin 1984: 16). Later, however, he grew increasingly critical of the British government and came to reject Unionist ideals. Ever since, Paulin has cherished the idea of a 'secular republic' in form of a United Ireland, in which all cultural traditions would be able to express themselves freely ( $c f$. Paulin 1984: 16). The line 'songs of a new society' communicate his wish for the creation of a new social order, in which social justice and equality would be guaranteed for both communities. Having evoked alternative ways of thinking through the figures of Plekhanov, Trotsky and Raskolnikov, Paulin points at the necessity of introducing innovative value and belief systems, in order to tackle social inequality in Northern Ireland. In his poem, he subversively opposes Russian Marxism to the established framework of Irish Nationalism and British Unionism and thus puts contrasting political ideologies into a dialogue. In so doing, he attempts to disrupt the traditionally one-sided discourse of the Northern Irish conflict, which in Bakhtin's terms could be considered as a "unitary language" (Bakhtin 1981: 271). Through the introduction of different 'voices' in terms of 'world views', Paulin pleads for plurality and the integration of opposing perspectives. The political ideologies and philosophical ideas embodied through Plekhanov, Trotsky and Raskolnikov function as "centrifugal forces", which aim at a "decentralisation" (Bakhtin 1981: 272) of traditional perceptions of the Troubles.

\section{Medbh McGuckian: 'The Man with Two Women'}

McGuckian's poetic approach differs considerably from Paulin's and Heaney's poetics. She introduces into her poetry a 'double stranded discourse' through a particular recourse to intertextuality. Many of her poems are constructed from unacknowledged quotes taken out of biographies on European writers and politicians written in English. A substantial number of her source texts refer to facts and figures closely connected to Russian literature or history. In this way, she generates a second narrative level into her poetry, establishing a coded dialogue between the voices of the source text and her own lines. McGuckian's poetry is marked by an associative, impressionistic character. Her aesthetic vision is resumed in her poem 'On Ballycastle Beach', whose lines read as a selfreflexive comment on her writing: "My words are traps/ through which you pick your way/ from a damp March to an April date,/ Or a mid-August misstep" (McGuckian 1995: 61). With the densely textured material of her poetry, she 
attempts to draw the reader into a "mesh of thoughts and a nexus of feelings" (McCracken 1990: 20) to encourage different angels of vision.

McGuckian's poem 'A Man with Two Women' is based on Ann and Samuel Charter's book I love, a biographic account of Vladimir Mayakovsky's relationship with his long-term lover Lili Brik (cf. Alcobia-Murphy 2006: 63). Through the underlying subtext of I Love, McGuckian turns Mayakovsky into the central character of her poem. In this way, she focuses on a writer who considered art as a means to promote the Revolution and who employed poetry as an instrument to influence society and politics. Even if McGuckian does not consider herself an overtly political poet, she shares Mayakovsky's view that poetry exercises an impact on politics: "I have not lost the conviction that poetry must strive after the beautiful, true and good, but the certainty that it affects politics and ought to has changed my attitude towards it” (Brandes 1997: 46). McGuckian was drawn to Mayakovsky, not only by their shared belief in the power of poetry, but also by the fact that her poems generated equal controversy as Mayakovsky's work did. Whereas the Russian poet was dismissed as a "versifying hooligan" (Blake 1975: 12), McGuckian's poetry was criticised as "gobbledegook" (Williams 1989: 50) or an "alluring sort of nonsense" (Simmons 1984: 27). As was the case for the Futurists, who protested against current literary traditions, proclaiming their aesthetics in their manifesto A Slap in the Face of Public Taste, McGuckian works against existing poetic conventions with her hermetic kind of poetry. Through the ambiguous use of her language and the coded references to Russia, she sets out to present the Northern Irish situation from an alienating angle and thus attempts to generate new manners of perceiving the political situation.

'A Man with Two Women' can be read as a sensual encounter between a man and a woman. The consideration of the source text, however, reveals a political context, linking Northern Ireland to revolutionary Russia. The title of the poem is to be seen as an allusion to the 'ménage à trois', in which Mayakovsky lived for fifteen years with Lili and her husband Osip. Nevertheless, McGuckian reverses the amorous constellation and entitles her poem 'The Man with Two Women', instead of 'The Woman with Two Men'. In so doing, she attempts to obscure her literary allusions and encourages a variety of interpretations. The title of her poem at the same time establishes a coded connection between Ireland and Russia through its double stranded meaning: ‘The Man with Two Women' on the one hand evokes a traditional Irish Folk song with the same title and on the other implicitly refers to 'The Man with Two Kisses', a character in Mayakovsky's farcical play 'Vladimir Mayakovsky: A Tragedy'. The graphic aspect of 'The Man with Two Women' also recalls Mayakovsky's poetry. As the Russian writer, McGuckian breaks up every line in the middle, letting it continue one line further down. In this way, she echoes Mayakovsky's quest for new poetic forms and new means of expression. 
Choosing I Love as a basis for her poem, McGuckian establishes a subversive connection to the Russian Revolution. Through the figure of Mayakovsky, she refers to political change and revolutionary ideas. Mayakovsky's personal and professional life was profoundly influenced by politics and his poetic work was shaped by Bolshevik ideas. As he devoted himself to the construction of a proletarian state, his whole existence became closely linked to the Revolution. In her poem, McGuckian interconnects allusions to Northern Ireland with quotations taken from I Love and thus establishes a parallel between a historical and a contemporary political conflict. Against the background of the source text, a number of references to the Revolution become apparent:

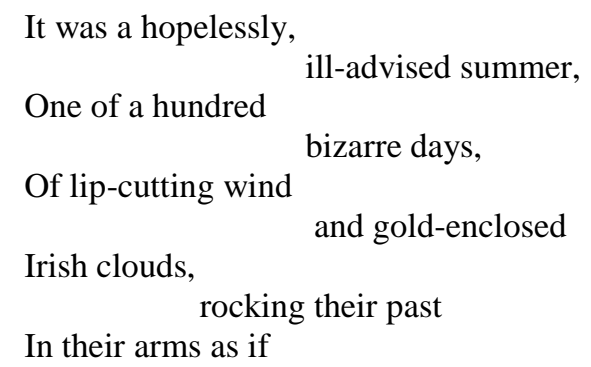

Army uniforms with

they were still in their

the shoulder-taps removed.

(McGuckian 1992: 14)

The 'ill-advised summer' and the 'hundred bizarre days', mentioned in the first lines, allude to Russia in the summer of 1917. After the downfall of the Tsar, the Provisional Government had launched "a hopelessly ill-advised summer offensive" (Charters 1979: 106). This military action turned out to be an entire failure as it led to mass desertions and deepened the distrust of the new government among the Russian population. The "hundred bizarre days" read as a reference to the period between the abdication of the Tsar in March and the seizure of power by Lenin in October 1917, a time when the Revolution hung in balance. In this way, McGuckian implicitly refers to political instability and violence in the first lines of her stanza. The allusion to Russian war politics reads as an implicit hint at the Troubles. 'The Man With Two Women' was written in 1992, two years before the first ceasefire declaration of the IRA. At that time, the situation in Northern Ireland was still unstable and an appeasement of the conflict was not yet in sight. McGuckian's assertion that Russia after 1917 resembled Northern Ireland after 1968, when it turned into "a seed-bed of conflict, a warzone" (Sewell 1993: 56) supports the assumption that in her poem, Russian 
history serves as an alternative framework through which she chooses to engage with the conflict.

The established correlation between Russian and Northern Ireland is further enforced through the subsequent lines of the poem. The term 'lip-cutting wind' is taken from a paragraph in I Love about Mayakovsky's excursion to the German Island Norderney. Mayakovsky's friend and travel companion Victor Shklovsky commented on their trip as follows: "Many things were going on then - rejection in love, and nostalgia, and youth. Memory has selected the sea and the wind. By that immense, alien sea, with its lip-cutting wind, our youth was ending" (Charters 1979: 196). The scenery of the German Island in the Northern Sea is transposed in McGuckian's poem to Northern Ireland through the coinage of the term 'lip-cutting' wind, which reminds us of the strong winds sweeping over the island. In Shklovsky's account of the journey, the wind takes on the symbol of emotional trouble. The mentioned nostalgia about youth implies closure and the coming to terms with the past. With "many things were going on", Shklovsky not only hints at private life but also at the Russian Revolution, which aimed at the deconstruction of the old social order. The images used by Shklovsky are taken up by McGuckian in the "gold-enclosed Irish clouds, rocking their past in their arms". In relation to Northern Ireland, these lines refer to the refusal of the two communities to come to terms with history and to reconsider old animosities. Thus, McGuckian suggests that Northern Irish society has to deal with its past in order to be able to move on.

The lines "as if they were still in their army uniforms with the shoulder-taps removed", refer to Mayakovsky, who fought in the Red Army for the Bolsheviks:

He went on insisting that the only artist who represented the Revolution were himself, Burliuk, and the other Futurists. He stormed into meetings, often still in his army uniforms with the shoulder taps removed, he harangued people who disagreed with him, he demanded over and over again that the Revolution should do away with all its past part (Charters 1979: 103).

In McGuckian's poem term 'army uniform' in relation to the 'golden enclosed Irish clouds' reminds us of the uniforms worn by British soldiers on Northern Irish streets. The fact that the shoulder taps are removed, but the uniforms are still worn, hints at the continuation of the conflict. Through the juxtaposition of the images "Irish clouds" and "uniforms", McGuckian establishes a relationship between Ireland and the British coloniser, evoking the themes of invasion and state control. Whereas the term 'army uniform' takes on the negative connotation of occupation, the 'Irish clouds' mentioned become glorified through their description as "gold enclosed". They seem to embody the ideal state of Ireland as a nation before the British invasion. Against the background of I Love, the reworking of history receives an additional meaning. Committed to the Futurist ideal of destroying the heritage of the past, Mayakovsky objected to the 
preservation of paintings and books, which dated from a time before the Revolution. Proclaiming: “The past suffocates us!” (Charters 1979: 29), the Futurists articulated their search for a new form of society and innovative ways of expression. It could be argued that McGuckian's striving to go against traditional poetic forms, communicates her desire to break free form the region's "suffocating" past and her wish to insert her personal voice into the discourse of the Troubles.

\section{Conclusion}

Establishing various links to Russia, Heaney, Paulin and McGuckian shed a defamiliarising light on Northern Ireland. Through the introduction of new perspectives, they attempt, speaking in Shklovsky's terms, to “deautomatise” ( $c f$. Shklovsky 1965: 22) the established perception of the Troubles. By making the familiar look strange, the three poets intend to draw the reader's attention to the extent of the Northern Irish conflict. According to Shklovsky, the vision of an object or state of affairs becomes automatic and thus unconscious as soon as it becomes habitual. Therefore, the aim of art is to prolong the reader's attention and to make him or her "create a special perception of the object" (Shklovsky 1965: 13). In this sense, Heaney, Paulin and McGuckian attempt to generate an unusual vision of the Troubles in order to work against an automatic perception of the conflict. Through the dialogisation of different world views and belief systems, the three poets refuse to enter the 'monologic' discourse lead by the British government and the media in order to propagate a biased version of the Northern Irish situation.

However, it could be asked whether the correlations between pre- and postRevolutionary Russia and Northern Ireland are justifiable. With regard to 'Chekhov on Sakhalin', the parallel created between Heaney and Chekhov could be seen as out of proportion. Even if the Irish and the Russian writer shared the same ethical concerns about creative writing in times of social inequality and oppression, their historical background was a different one. Whereas Chekhov lived in an autocratic monarchy, Heaney was not exposed to the repression of a totalitarian system. Furthermore, the comparison Paulin and McGuckian attempt to make between revolutionary Russia and Northern Ireland could be regarded as overstated. Considering the fact that the Russian Revolution affected one of the world's biggest empires and brought death to millions of people, the analogy established with Northern Ireland appears exaggerated. In this context, the correlation created between the Bolsheviks and the British government in their role as oppressors appears daring. However, Heaney, Paulin and McGuckian may have deliberately used the technique of defamiliarisation in their poems in order to transfer the Northern Irish situation from a national into a global context and thus highlight the consequences of the political violence committed. Therefore, the parallels established are to be seen as intended overstatements rather than as 
comparisons in documentary terms. Playing with exaggeration and amplification, the three poets echo Paul Muldoon, who argues: "The point of poetry is to be actually discomforting, to prod and provoke, to poke us in the eye, to punch us in the nose, to knock us off our feet, to take our breath away" (Muldoon 1998: 516). With their deliberately provocative poetry, Heaney, Paulin and McGuckian plead for an innovative vision of the Northern Irish conflict through the integration of contrasting voices and perceptions.

École des Hautes Études en Sciences Sociales, Paris,

France

\section{References}

Alcobia-Murphy, S., 2006, Sympathetic Ink. Intertextual Relations in Northern Irish Poetry, Liverpool: Liverpool University Press.

Applebaum, A., 2003, Gulag. A History, London: Penguin.

Bakhtin, M., 1981, 'Discourse in the Novel', in: The Dialogic Imagination. Four Essays by M. M. Bakhtin, Austin: University of Texas Press, 259-422.

Blake, P., ed., 'Introduction', in: Vladimir Mayakovsky the Bedbug and Selected Poetry, New York: Midland Book.

Brandes, R., 1997, 'A Dialogue with Medbh McGuckian', Studies in the Literary Imagination 30.2, 47.

Charters, A., \& Charters, S., 1979, I Love. The Story of Vladimir Mayakovsky and Lili Brik, New York: Farrar.

Chekhov, A., 1977, The Island. A Journey to Sakhalin, trans. Trepak, L. \& Trepak, M., Westport: Greenwood Press.

Heaney, S., 1984, Station Island, London: Faber.

Heaney, S., 1988, The Government of the Tongue, London: Faber.

Heaney, S., 1995, The Redress of Poetry, London: Faber.

McCracken, K., 1990, 'An Attitude of Compassion', The Irish Literary Supplement, 20.

McGuckian, M., 1992, Marconi's Cottage, Winston-Salem: Wake Forest University Press.

McGuckian, M., 1995, On Ballycastle Beach, Oldcastle: Gallery Books.

Paul Muldoon, P., 1998, 'The Point of Poetry', Princeton University Library Chronicle 49.3, Spring, 516.

Paulin, T. 1980, The Strange Museum, London: Faber.

Paulin, T. 1984, Ireland and the English Crisis, Newcastle: Bloodaxe Books.

Ryfa, J. T., 1999, The Problem of Genre and the Quest for Justice in Chekhov's 'The Island of Sakhalin', Lewiston: The Edwin Mellen Press. 
Shklovsky, V., 1965, 'Art as Technique’, in: Lemon, L. \& Reiss, M. J., trans./ed., Russian Formalist Criticism. Four Essays, Lincoln: University of Nebraska Press, 3-24.

Simmons, J., 1984, ‘A Literary Leg-Pull?’, Belfast Review 8, 27.

Williams, P., 1989, 'Spare that Tree’, Honest Ulsterman 86, 50. 